\title{
Da imitação à inovação: a dinâmica do aprendizado tecnológico da C oréia
}

\author{
Linsu Kim \\ Campinas, SP: Editora da U N ICAM P, 2005.
}

No que pese os custos das distorções incorridas, o processo de industrialização brasileiro logrou em transformar uma típica economia exportadora de bens primários em outra detentora de uma ampla estrutura produtiva. No período de apenas meio século transcorrido entre 1930 e 1980 , formaria-se no país um parque industrial diversificado, ainda que por meio de mecanismos protecionistas, subsídios creditícios e fiscais, e preços defasados tanto de serviços públicos quanto de determinados produtos das empresas estatais. De qualquer forma, esse cenário não seria muito diferente ao encontrado em outros países - como, por exemplo, a Coréia do Sul - que acabariam por se destacar ao longo das décadas seguintes. De fato, a diferença que determinaria as distintas trajetórias tomadas pelos dois países residia em sua orientação competitiva: enquanto o planejamento econômico deste país asiático tinha como meta a inserção em mercados externos, o caso brasileiro tinha como objetivo a satisfação da demanda interna por produtos anteriormente importados. Dentro deste contexto, a obra de Linsu Kim, "Da imitação à inovação: a dinâmica do aprendizado tecnológico da Coréia", lança luz sobre alguns dos aspectos que ajudam a explicar os diferentes caminhos traçados pelos países latino-americanos e asiáticos no trasnscorrer das últimas décadas.

Linsu Kim, falecido no início de 2003, foi de fato um dos pioneiros na análise do processo de aprendizagem tecnológico da Coréia do Sul, sendo que "Da imitação à inovação" ficaria como sua obra mais importante. Curiosamente, seu lançamento se daria em um momento infeliz, em meio à crise asiática de 1997, o que exacerbaria o tom às vezes excessivamente entusiasta em relação à estratégia de desenvolvimento adotada por esse país. Porém, passado quase uma década desde então, no que pese esse teor por vezes engajado, muitas lições podem ser extraídas da obra.

O livro se divide em três partes. Na primeira delas, o autor expõe o cenário sul-coreano sob o qual se deu o processo de aprendizagem tecnológica. Ela é constituída por dois capítulos, nos quais se discute, respectivamente, o papel do Es- tado e das políticas industriais, e o sistema educacional e os fatores sócio-culturais condicionantes daquele processo. É nesta parte que ficam evidentes certas particularidades da economia sulcoreana que tornam sua experiência um tanto singular, notadamente o alcance de poder do Estado sobre as instituições de mercado e sobre o próprio comportamento do empresário e do trabalhador. O autor, de todo modo, busca salientar que, mesmo após a democratização política ocorrida na década de 1980, a partir de um redesenho de suas instituições, os condicionantes favoráveis ao processo de aprendizagem permaneceriam presentes, sujeitando-se somente à devida mudança de paradigma.

A segunda parte, então, é dedicada à análise de determinados estudos de caso, constituindo-se o ponto principal do livro. Após introduzir, no capítulo quatro, o arcabouço teórico sob o qual se dará essa análise, o autor expõe a trajetória das indústrias automobilísticas, de produtos eletrônicos, de semicondutores e das pequenas e médias empresas. São explicitadas então as estratégias tomadas pelo governo e pelas empresas de cada um desses setores em vistas ao aprendizado tecnológico, ou seja, ao caminho traçado dentro desses setores com relação ao processo que daria o título à obra — da imitação à inovação.

Já na última parte, Linsu Kim delineia as implicações da experiência sul-coreana para os demais países em processo de catching-up. $\mathrm{O}$ autor salienta quatro aspectos que poderiam ser reproduzidos por esses países: a atuação governamental, as políticas industriais e educacionais e, por fim, a construção de crises por parte do governo.

Porém, Kim faz ainda algumas ressalvas. Primeiramente, a respeito das diferenças ambientais que hoje já não são mais reproduzíveis, principalmente em virtude das regras da Organização Mundial do Comércio (OMC), da proteção dos direitos de propriedade intelectual e das políticas protecionistas dos Estados Unidos e da Europa tornando-se um empecilho a uma estratégia de desenvolvimento voltada às exportações.

Em segundo lugar, Kim aponta certas parti- 
cularidades do processo sul-coreano, como os fatores culturais que moldam e disciplinam o comportamento individual e grupal, que claramente não são passíveis de serem reproduzidos. Ainda, as dificuldades impostas pela Guerra da Coréia, pelas condições físicas do país e por uma série de privações históricas teriam sido, segundo o autor, fundamentais para, respectivamente, a transformação da sociedade sul-coreana, a capacidade de adaptação e a origem do espírito empreendedor e da dedicação ao trabalho por parte dos sul-coreanos.

Finalmente, o autor conclui recorrendo ao Paradoxo de Ícaro, segundo o qual a maior vantagem de uma pessoa sobre as demais pode transformar-se no fator determinante de sua queda. Fazendo a analogia com a economia sul-coreana, o autor aponta quatro desses fatores: a grande intervenção do governo na economia, a concentração econômica em torno das grandes corporações — os chaebols -, a preservação da cultura e do idioma nacionais, e a organização militarista e verticalizada das empresas sul-coreanas.

Com tudo isso, pode-se dizer que o lançamento dessa obra no Brasil veio em boa hora. Ao mesmo tempo em que o país se mostra incapaz de apresentar significativas taxas de crescimento econômico por mais de dois anos consecutivos, diversos setores da sociedade têm se mostrado insatisfeitos com as respostas dadas pelo atual debate econômico. A obra de Linsu Kim constitui então um importante subsídio ao aprimoramento desse debate, particularmente no que diz respeito a políticas de incentivo à inovação tecnológica e à inserção competitiva em mercados internacionais.

Alexandre M essa Silva Pesquisador do IPEA, Professor do Departamento de Economia da Universidade de Brasília e Mestre em Economia pela EAESP/FGV. 